\title{
С.Г. Вакарчук
}

\section{ПЕРСПЕКТИВИ ПОШУКІВ СКУПЧЕНЬ НЕКОНВЕНЦІЙНОЇ НАФТИ В КАРБОНАТНИХ ВІДКЛАДАХ ПАЛЕОЗОЙСЬКОГО КОМПЛЕКСУ ДНІПРОВСЬКО-ДОНЕЦЬКОЇ ЗАПАДИНИ}

Розглянуто питання перспективності карбонатних утворень палеозойського комплексу Дніпровсько-Донецької западини на формування скупчень неконвенційної нафти. На основі комплексного аналізу геолого-промислових і геолого-геофізичних матеріалів у розрізі палеозойського комплексу виділено п'ять основних стратиграфічних рівнів розповсюдження карбонатних порід, перспективних на пошуки неконвенційної нафти, і визначено просторові закономірності їх локалізації.

Ключові слова: нетрадиційна нафта, карбонати, термальна зрілість, органічна речовина, Дніпровсько-Донецька западина.

Вступ. За останні 10 років видобуток нафти в Дніпровсько-Донецькій западині (ДДЗ) зменшився на 0,880 млн т (36,0\%) - 32,427 млн т у 2006 р. до 1,547 млн т у 2014 р. Приріст запасів нафти за цей же період скоротився на 0,973 млн т (55,9\%) - 1,739 млн т у 2006 р. до 0,766 млн т у 2015 р. Останнім часом жодного крупного і середнього за запасами нафтового родовища в регіоні відкрито не було. Здебільшого запаси нових відкритих родовищ не перевищують 0,5-1,0 млн т, що напряму пов'язано з невеликими розмірами перспективних об'єктів, що вводились у пошукове буріння. Аналіз фонду виявлених і підготовлених до глибокого буріння об'єктів також свідчить про відсутність можливостей відкриття найближчим часом значних за запасами нафтових родовищ, освоєння ресурсів яких дало б можливість припинити падіння видобутку. В той же час аналіз досвіду проведення геологорозвідувальних робіт в «старих» нафтогазовидобувних регіонах Північної Америки показує, що одним із шляхів стабілізації і подальшого нарощування видобутку нафти $€$ освоєння ії неконвенційних скупчень в сланцевих утвореннях і ущільнених породах [7-9]. Яскравим прикладом в цьому відношенні $€$ Сполучені Штати Америки, яким вдалося за рахунок освоєння нетрадиційних джерел вуглеводнів збільшити щорічний загальний видобуток нафти з 302,3 млн т у 2008 р. до 519,9 млн т у 2014 р. 3 огляду на це в сучасних умовах для Східного нафтогазоносного регіону України є цілком актуальним інтенсифрікувати дослідження по проблемі пошуку неконвенційної нафти. За попередніми даними одним із перспективних об'єктів в цьому напрямі $є$ ущільнені карбонатні утворення палеозойського комплексу.

Стан проблеми. Вивчення проблеми пошуку нетрадиційної нафтти в ДДЗ знаходиться на початковій стадії. Найбільш повно досягнуті на сьогодні результати досліджень теоретичних і практичних аспектів пошуку неконвенційної нафти в даному регіоні викладені в циклі наукових монографій [2, 3]. В той же час у даних публікаціях основна увага приділялася оцінці перспектив нафтоносності сланцевих і ущільнених теригенних утворень. Перспективи пошуку неконвенційної нафти в ущільнених карбонатних породах практично не наводилися. Якоюсь мірою дана проблема була розглянута лише для верхньодевонських карбонатних відкладів північно-західної частини ДД3 [4].

Матеріали та методи досліджень. В основу роботи покладено результати аналізу геологопромислових даних та дані піролітичних і петрофізичних досліджень по 420 свердловинах пробурених у межах ДДЗ, яка в цілому відповідає Східному нафтогазоносному регіону України.

Всього у роботі було використано результати понад 500 аналізів петрофрізичних властивостей порід, 840 аналізів катагенетичної зрілості порід, 120 визначень С орг, 150 рентгено-структурних аналізів і понад 600 описів керна та шліфів. Також з метою виділення у розрізі інтервалів залягання порід, перспективних на неконвенційні вуглеводні, та оцінки їх промислових параметрів було виконано комплексну інтерпретацію матеріалів ГДС 32 свердловин із застосуванням спеціалізованих методик.

(С) С.Г. Вакарчук, 2015 
Результати досліджень. Критерії оцінки перспектив пошуку неконвенційної нафрти у карбонатних породах. Виділення перспективних в нафтоносному відношенні ущільнених карбонатних порід базувалося на системі критеріїв, які були розроблені на основі аналізу та узагальнення даних по осадових басейнах і суббасейнах Північно-Американського континенту, де проводиться промислове видобування нетрадиційної нафти - Уїллістоун, ІглФорд, Барнетт, Марселлус та Вудфорд.

Основні геолого-технічні критерії оцінки перспектив нафтоносності ущільнених карбонатних утворень на стадії пошуку викладені нижче.

1. Літологічний склад порід. У літологічному відношенні найбільш перспективними для пошуку неконвенційної нафрти в карбонатних утвореннях $\epsilon$ гідрокарбопеліти, глинисті зернисті і детритові вапняки, глинисті доломіти, чисті вапняки і доломіти, рідше мергелі. В фаціальному відношенні це в основному шельфові і відкритобасейнові відклади.

2. Вміст органічної речовини. Одним із основних критеріїв для оцінки перспективності карбонатних утворень на пошуки неконвенційної нафтт є вміст у породі органічної речовини

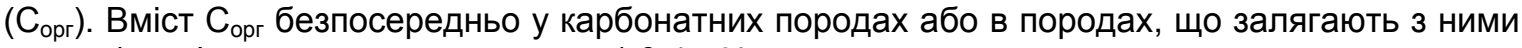
в параґенезі, повинен перевищувати 1,0-1,5\%.

3. Тип органічної речовини. Найбільш перспективними для пошуку неконвенційної нафти є породи, збагачені органічною речовиною в складі якої переважають сапропеліти, а гумусова складова відіграє підпорядковану роль (тип I та II). Саме органічна речовина сапропелевого і гумусово-сапропелевого типів при термальному перетворенні здатна генерувати основні об'єми рідких вуглеводнів.

4. Ступінь термальної зрілості порід. Перспективними для генерації нафти є породи, що знаходяться в інтервалі від верхньої частини $\mathrm{MK}_{1}\left(\mathrm{R}^{\circ}-0,55\right)$ до середньої частини МК $\left(R^{\circ}-0,95\right)$. Однак найбільші перспективи слід пов'язувати з інтервалом від $R^{\circ}-0,6$ до $R^{\circ}-$ 0,8, що відповідає, за іноземною термінологією, так званому «нафтовому вікну».

5. Пористість і проникність порід. На сьогодні нижня межа пористості порід, з яких здійснюється основний обсяг видобування неконвенційної нафти, становить $2 \%$, проникності - 0,1 мД. Варто зазначити, що в окремих випадках, при широкому розвитку в породах тріщинуватості, мінімальні значення пористості можуть становити і 1,0-1,5\%.

6. Товщина і глибина перспективного горизонту. Аналіз розробки скупчень сланцевої нафти у Північній Америці показує, що глибина залягання пластів, з яких здійснюється основний обсяг видобування, змінюється від 200 до 4500 м. Товщина перспективних пластів теж коливається в широких межах, однак, як правило, перевищує 25-30 м.

Комплексний аналіз геолого-промислових, геолого-геофізичних та геолого-геохімічних матеріалів по карбонатних фрормаціях палеозойського комплексу на основі визначених критеріїв дозволив виділити п'ять основних стратиграфічних рівнів розповсюдження карбонатних порід, які $€$ перспективними на пошуки скупчень неконвенційної нафти. Два рівня виділено у відкладах девонського комплексу - саргаєвський та семилуцький горизонти нижньофранського під'ярусу і задонський горизонт нижньофраменського під'ярусу. У відкладах кам'яновугільного комплексу виокремлено три рівня - турнейський ярус, нижньовізейський під'ярус і нижньобашкирській під'ярус. Карбонатні утворення нижньопермського комплексу через низький вміст $\mathrm{C}_{\text {орг }}$ і недостатню зрілість органічної речовини для генерації вуглеводнів $€$ безперспективними на пошуки неконвенційної нафти.

Карбонатні відклади саргаєвського та семилуцького горизонтів нижньофрранського під'ярусу. Ці відклади на глибинах до 4500 м розвинуті лише в межах окремих зон північнозахідної частини ДДЗ. У літологічному відношенні вони представлені органогенними сильно перекристалізованими шламово-детритовими, детритовими і грудкуватими вапняками, зернистими вапняками, седиментаційними і вторинними доломітами, а також мергелями. Формування карбонатних відкладів саргаєвського та семилуцького горизонтів відбувалося у мілководно-морському басейні з нормальною солоністю. Загальна товщина відкладів цих горизонтів - 20-80 м. Товщина окремих карбонатних пачок - від 2-5 до 30-40 м. Відкрита пористість карбонатних порід саргаєвського та семилуцького горизонтів змінюється від 1,0 до 7,5\%. Середні значення проникності, як правило, не перевищують 0,1-0,2 мД, однак на ділянках розвитку тріщинуватості можуть сягати 5,0-7,5 мД (у поодиноких випадках 15 мД). 
Ступінь катагенезу порід коливається від $\mathrm{R}^{\circ}-0,65$ (закінчення $\mathrm{MK}_{1}$ ) до $\mathrm{R}^{\circ}-1,8$ (середина $\mathrm{MK}_{5}$ ). Вміст $\mathrm{C}_{\text {орг }}$ у карбонатних і супутніх глинистих породах змінюється від 0,5 до 2,0\%. Органічна речовина гумусово-сапропелевого типу (тип II). За результатами аналізу розподілу визначених критеріїв у відкладах саргаєвського та семилуцького горизонтів нижньофранського під'ярусу закартована зона поширення карбонатних порід, перспективних на пошуки неконвенційної нафтти (див. рисунок). Загальна площа перспективних територій $1355 \mathrm{kм}^{2}$.

Карбонатні відклади задонського горизонту нижньофраменського під’ярусу. Ці відклади, як і відклади саргаєвського та семилуцького горизонтів нижньофрранського під'ярусу, на глибинах до 4500 м поширені лише в межах окремих зон північно-західної частини ДДЗ. Тут вони представлені зернистими і детритовими перекристалізованими вапняками з підпорядкованою роллю доломітів, біоморфних вапняків і мергелів. Загальна товщина відкладів задонського горизонту - 200-500 м. Товщина окремих карбонатних пачок - від 5-6 до 50-70 м. Відкрита пористість карбонатних порід задонського горизонту змінюється від 2,6 до 5,5\%. Середні значення проникності, як правило, не перевищують 0,10,15 мД. У доломітизованих різновидах значення відкритої пористості зростають до 4,4-8,2\%,

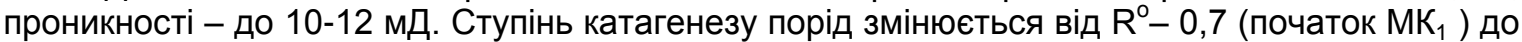
$\mathrm{R}^{\circ}-1,55$ (закінчення $\mathrm{MK}_{4}$ ). Вміст $\mathrm{C}_{\text {орг }}$ у карбонатних породах коливаються від 0,8 до 2,4\%, $\mathrm{y}$ супутніх глинистих породах - від 1,2 до 5,8\%. Органічна речовина в основному сапропелевого типу (тип I). Розповсюдження карбонатних порід, перспективних на пошуки скупчень нафти неконвенційного типу в відкладах задонського горизонту нижньофраменського під'ярусу наведено на рисунку. Загальна площа перспективних території - $125 \mathrm{kм}^{2}$.

Карбонатні відклади турнейського ярусу. Зазначені відклади на глибинах до 4500 м поширені в основному в межах південної прибортової зони південно-східної частини ДДЗ. У фаціальному відношенні це утворення переважно шельфової фаціальної зони [5]. У складі карбонатних порід переважають різноманітні детритові, шламово-детритові, згусткові, зернисті вапняки. Рідше трапляються біоморфні, біоморфоно-детритові вапняки та вторинні доломіти. Максимальна товщина карбонатних відкладів у межах цієї зони сягає 300-350 м. Товщина окремих пластів варіює від 30 до 110 м. Термальна зрілість порід турнейського ярусу в межах цієї території змінюється від $\mathrm{R}^{0}-0,55$ (середина $\mathrm{MK}_{1}$ ) до $\mathrm{R}^{0}-1,3$ (середина $\mathrm{MK}_{4}$ ). Вміст $\mathrm{C}_{\text {орг }}$ у карбонатних породах турнейського ярусу коливається від 0,2 до 1,7\%, в супутніх глинистих породах - від 0,8 до 3,5\%. Тип органічної речовини переважно сапропелевий (тип I), рідше гумусово-сапропелевий (тип II). Фільтраційно-ємнісні властивості карбонатних порід турнейського ярусу в цілому невисокі. Так, середні значення відкритої пористості не перевищують 3-4\%, а проникності - 0,01-0,1 мД. У той же час на окремих ділянках за рахунок розвитку вторинних пустот і тріщинуватості значення пористості

зростають до 14-16\%, а проникності - до 140-180 мД. За результатами комплексного аналізу геолого-геофізичних і геолого-промисловах даних, з використанням визначених критеріїв у відкладах турнейського ярусу була виділена і закартована територія поширення карбонатних порід, перспективних на пошуки неконвенційної нафти (див. рисунок). Площа

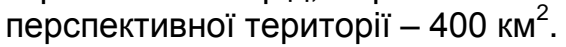

Карбонатні відклади нижньовізейського підярусу. Ці відклади розвинуті в межах південної і північної прибортових зон практично в усіх частинах западини, за винятком ії крайової північно-західної частини, де нижньовізейські відклади представлені в основному теригенними утвореннями. Товщина карбонатних відкладів нижньовізейського під'ярусу в межах цих територій змінюється від 20-25 до 250-300 м. У фаціальному відношенні це відклади переважно шельфової, рифрової і лагунної фраціальних зон. Літологічно карбонатні породи нижньовізейського під‘ярусу в межах цієї території представлені здебільшого різноманітними детритовими вапняками з підпорядкованою роллю шламово-детритових, біоморфних, біоморфно-детритових та зернистих вапняків. На окремих ділянках біоморфні і біоморфно-детритові вапняки фрормують органогені споруди, з якими в ДДЗ пов'язаний ряд традиційних родовищ вуглеводнів $[1,5]$. Середні значення відкритої пористості карбонатних порід - 2,5-4,5\%, проникності - 0,05-0,1 мД. Слід підкреслити, що на ділянках розвитку 


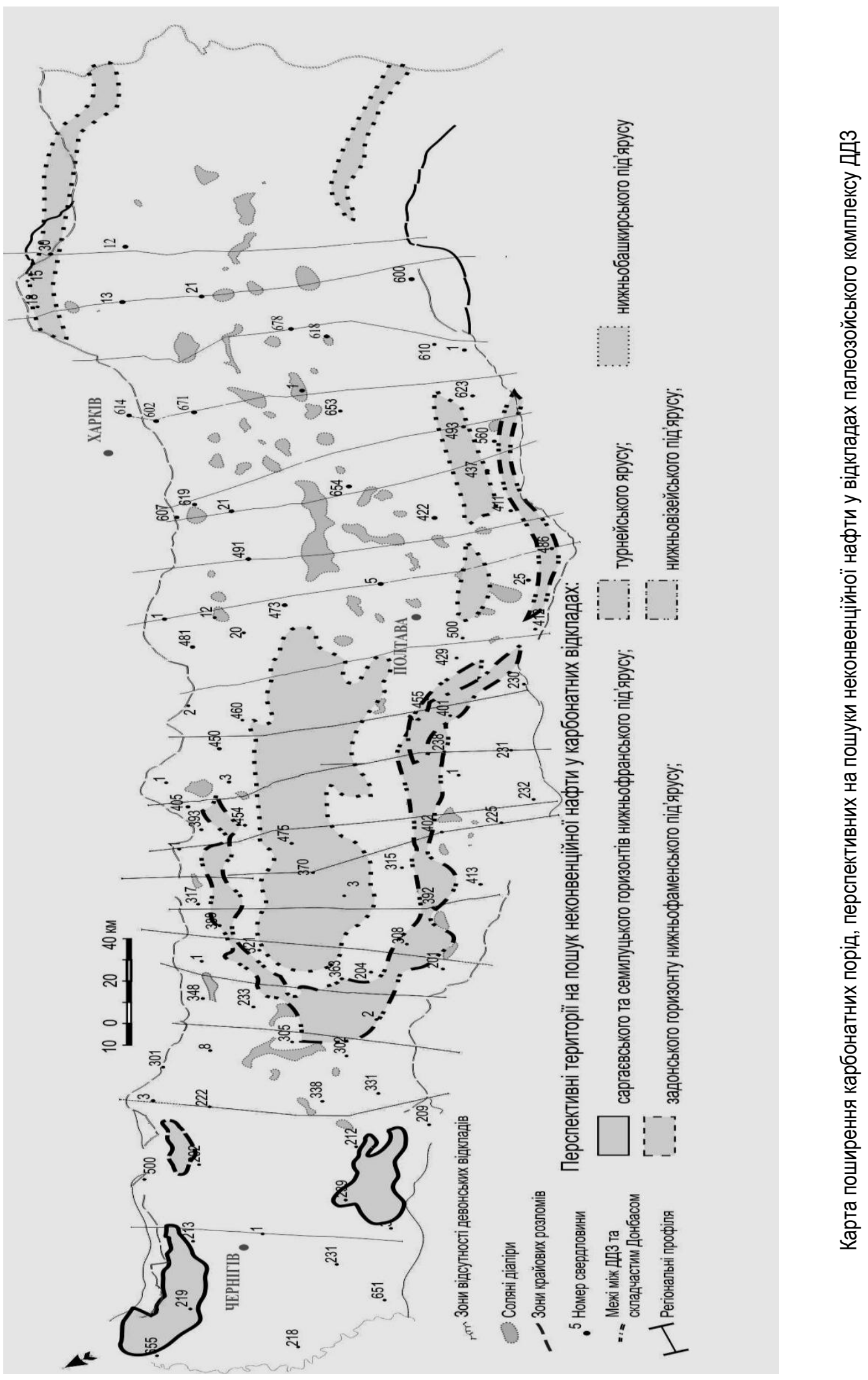


органогенних споруд значення пористості і проникності карбонатних порід різко зростають до 6-7\% (в поодиноких випадках до 22\%) і до 0,5-1,0 мД (подекуди до 146 мД), відповідно. Термальна зрілість карбонатних порід нижньовізейського підяярусу змінюється від $\mathrm{R}^{0}-0,45$ (середина ПК д $_{3} \mathrm{R}^{0}-1,55$ (закінчення $\mathrm{MK}_{4}$ ). Вміст $\mathrm{C}_{\text {орг }}$ у карбонатних відкладах нижньовізейського підяярусу - 0,1-1,5\%, в супутніх їм глинистих породах - 0,9-3,5\%. Тип органічної речовини - гумусово-сапропелевий (II типи), рідше сапропелевий (тип I) i сапропелево-гумусовий (тип III). За результатами комплексного аналізу геолого-геофізичних і геолого-промисловах даних, 3 використанням визначених критеріїв у відкладах нижньовізейського під'ярусу була виділена і закартована територія поширення карбонатних порід, перспективних на пошуки неконвенційної нафти (див. рисунок). Площа перспективної території- 3135 км². $^{2}$.

Карбонатні відклади нижньобашкирського під‘ярусу. Вказані відклади на глибинах до 4500 м широко поширені в межах осьової і прибортових зон западини i, частково, на ії бортах. У фраціальному відношенні це шельфові і лагунні утворення. При цьому відклади лагунної фаціальної зони локалізуються в основному в межах північно-західної і центральної частин ДДЗ, а шельфові - у межах південно-східної її частини. Літологічно карбонатні породи нижньобашкирського під'ярусу представлені різноманітними органогенними вапняками (шламово-детритовими, детритовими, біоморфними, біоморфноо-детритовими), мікрозернистими вапняками і первинними та вторинними доломітами. На окремих ділянках біоморфні та біоморфно-детритові водоростеві вапняки утворюють невеликі за розмірами органогенні споруди. Сумарна товщина пластів, що складаються з карбонатних порід, змінюється від 5-10 до 90-130 м. Відкрита пористість нижньобашкирських карбонатних порід коливається від 2-3 до 18-22\%, однак середні значення не перевищують 3-5\%. Середні значення проникності - 0,1-0,5 мД. Ступінь катагенезу порід варіює в широких межах - від $\mathrm{R}^{\circ}-0,40$ (закінчення ПК $_{2}$ ) до $\mathrm{R}^{\circ}-1,8$ (середина $\mathrm{MK}_{5}$ ). Причому найменші значення зафріксовані в межах бортових зонах западини, а найбільші в межах її осьової частини. Також зростання термальної зрілості нижньобашкирських карбонатних порід відмічається в південно-східному напрямку. Вміст $\mathrm{C}_{\text {орг }}$ у карбонатних породах нижньбашкирського під'ярусу - 0,4-1,3\%, в супутніх їм глинистих породах - 0,8-1,8\%. Тип органічної речовини - гумусовосапропелевий (тип I). За результатами досліджень і картування основних прогнозних параметрів вдалося виділити декілька зон поширення ущільнених карбонатних порід нижньобашкирського під'ярусу, перспективних в нафртовому відношенні (див. рисунок).

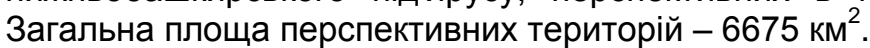

Висновки. За результатами проведених досліджень в розрізі палеозойського комплексу ДД3 виділено п'ять стратиграфічних рівнів розповсюдження карбонатних порід, перспективних на пошуки нафти неконвенційного типу: саргаєвський та семилуцький горизонти нижньофранського під'ярусу і задонський горизонт нижньофаменського підя'русу верхньодевонського комплексу, турнейський ярус і нижньовізейський під'ярус нижньокам'яновугільного комплексу та нижньобашкирський під'ярус середньокам'яновугільного. Найбільше карбонатні породи, перспективні на неконвенційну нафту, поширені у відкладах нижньобашкирського і нижньовізейського під'ярусів кам'яновугільного комплексу, дещо менше - у відкладах саргаєвського та семилуцького горизонтів нижньофранського під'ярусу верхньодевонського комплексу. У відкладах задонського горизонту нижньофраменського під'ярусу і турнейського ярусу породи, які можуть становити інтерес для пошуку неконвенційної нафти, розвинуті локально. Загальна площа територій поширення карбонатних порід, перспективних на пошуки неконвенційної нафти, по усіх комплексах - 11690 км². Першочерговими об'єктами для проведення подальших детальних досліджень $€$ карбонатні відклади нижньобашкирського і нижньовізейського під“ярусів кам'яновугільного комплексу в північно-західній частині ДДЗ.

\section{СПИСОК ЛІТЕРАТУРИ}

1.Вакарчук С.Г. Геологія, літологія і фації карбонатних відкладів візейського ярусу центральної частини ДніпровськоДонецької западини в зв'язку з нафтогазоносністю / Вакарчук С.Г. - Чернігів: ЦНТТЕІ, 2003. - 163 с. 
2. Вакарчук С.Г. Нетрадиційні джерела вуглеводнів України. Кн. 6. Перспективи освоєння ресурсів газу ущільнених порід у Східному нафтогазоносному регіоні України / С.Г. Вакарчук, Т.Є. Довжок, К.К. Філюшкін та ін. - К.: ТОВ «ВТС ПРИНТ», 2013. -207 c.

3. Вакарчук С.Г. Нетрадиційні джерела вуглеводнів України. Кн. 5. Перспективи освоєння ресурсів сланцевого газу та сланцевої нафти у Східному нафтогазоносному регіоні України / Вакарчук С.Г., Зейкан О.Ю, Довжок Т.Є. та ін. - К.: ТОВ «ВТС ПРИНТ», 2013. - $240 \mathrm{C}$.

4.Вакарчук С.Г. Перспективы поисков углеводородов неконвенционного типа в девонских отложениях северо-западной части Днепровско-Донецкой впадины / Вакарчук С.Г., Філюшкін К.К. // Літасфрера. - 2014. - № 2 (41). - С. 117-124.

5.Лукин А.Е. Турнейско-нижневизейский рифогенно-карбонатный комплекс Днепровско-Донецкой впадины и общие проблемы формирования раннекаменноугольных нефтегазоносных рифов / Лукин А.Е., Вакарчук С.Г. // Геол. журн. 1999. - № 2 (288). - С. 21-33.

6. Михайлов В.А. Нетрадиційні джерела вуглеводнів України. Кн. 8. Теоретичне обгрунтування ресурсів нетрадиційних вуглеводнів осадових басейнів України / В.А. Михайлов, С.Г. Вакарчук, О.Ю. Зейкан та ін. - К.: НІКА-ЦЕНТР, 2014. - 280 C.

7. Jaffe A.M. The status of world oil reserves: conventional and unconventional resources in the future supply mix / Jaffe A.M., Medlock K.B., Soligo R. // James A. Baker III Inst. for Public Policy, Rice University, 2011. - 40 p.

8. Mature region, youthful potential. Oil and Natural Gas Resources in the Appalachian and Illinois Basins // Report by the Appalachian and Illinois Basin Directors of the IOGCC. - 2005. - $30 \mathrm{p}$.

9. Pickett A. New technology allows Mid-Continent's operators to capture new reserves / Pickett A. // American Oil \& Gas Reporter. - 2012. - Vol. 55, no. 10.- P. 82-98.

\section{С.Г. Вакарчук \\ ПЕРСПЕКТИВЫ ПОИСКОВ НЕКОНВЕНЦИОННОЙ НЕФТИ В КАРБОНАТНЫХ ОТЛОЖЕНИЯХ ПАЛЕОЗОЙСКОГО КОМПЛЕКСА ДНЕПРОВСКО-ДОНЕЦКОЙ ВПАДИНЫ}

Рассмотрены вопросы перспективности карбонатных образований палеозойского комплекса ДнепровскоДонецкой впадины на формирование скоплений неконвенционной нефти. На основе комплексного анализа геолого-промысловых и геолого-геофизических материалов в разрезе палеозойского комплекса выделено пять основных стратиграфических уровней распространения карбонатных пород, перспективных на поиски неконвенционной нефти, и определены пространственные закономерности их локализации.

Нетрадиционная нефть, карбонаты, термальная зрелость, органическое вещество, Днепровско-Донецкая впадина.

\section{S. Vakarchuk \\ EXPLORATION PERSPECTIVES FOR UNCONVENTIONAL OIL IN THE PALEOZOIC CARBONATE FORMATIONS OF THE DNIEPER-DONETS DEPRESSION}

The paper features are the problem of exploration perspectives for unconventional oil accumulations in the Paleozoic carbonate formations within Dnieper-Donets depression. An integrated analysis of the geological, geophysical and industrial data has allowed recognition of five basic stratigraphic levels prospective for unconventional oil exploration in the carbonate formations and spatial delineation of those rocks localization were defined.

Keywords: unconventional oil, carbonates, thermal maturity, organic matter, Dnieper-Donets depression..

Дочірнє підприємство «Науково-дослідний інститут нафртогазової промисловості» Національна акціонерна компанія «Нафтогаз України». Україна, Київська область, м. Вишневе

Вакарчук Сергій Григорович

e-mail: vakarchuk@naukanaftogaz.kiev.ua

Стаття надійшла: 13.04 .2015 